Свєшніков С. В., канд. техн. наук, ст. наук. співроб.

Центр воєнно-стратегічних досліджень Національного університету оборони України імені Івана Черняховського, Київ

\title{
Інтереси провідних воснно-політичних сил як головні детермінанти розвитку безпекового середовища в контексті безпеки України
}

Резюме. У статті розглянуто інтереси провідних воєнно-політичних сил світу, які визначатимуть розвиток безпекового середовища у довгостроковій перспективі.

Ключові слова: воєнно-політичні сили; безпекове середовище; оборонне планування; національні інтереси; передбачення.

Постановка проблеми. У 2020 році закінчився черговий цикл оборонного планування в Міністерстві Оборони України та Збройних Силах України, в основу якого було покладено довгострокове передбачення розвитку безпекового середовища на перспективу до 2030 року. Завдання щодо розроблення такого передбачення було поставлено вперше за історію Збройних Сил України. Для вирішення завдання необхідно було, по-перше, обрати метод або навіть концепцію передбачення i, по-друге, застосувати ii на наявних даних. Обидва питання мають вирішуватись 3 огляду на забезпечення безпеки України. Оскільки раніше ці завдання не ставились перед вітчизняною наукою, концептуальні положення щодо науково обгрунтованого передбачення довгострокового майбутнього 3 огляду на забезпечення безпеки України не пророблювались (принаймні авторам не відомі такі спроби). Закордонні концепції і технології передбачення теж недоступні через певну “делікатність" питання, хоча деякі ідеї опосередковано можна виявити. Зрозуміло, що довгострокове прогнозування пов'язане 3 аналізом надвеликої кількості вхідних змінних. Виявити їх точне сполучення в далекому майбутньому практично неможливо, оскільки пов'язане 3 розглядом незлічених комбінацій. Єдиним виходом тут може бути пошук системних детермінант, які концентрують у собі головні, узагальнені важелі розвитку безпекового середовища. Отже, виникає суперечність між потребою надання науково обгрунтованих вихідних даних для оборонного планування та відсутністю концепції передбачення еволюції безпекового середовища у довгостроковій перспективі, в основі якої має бути покладений розгляд системних детермінант.
Аналіз останніх досліджень i публікацій. Достатньо детальній аналіз відомих методів, які засновані на явному або неявному продовженні існуючих трендів, наведено в роботі [1]. Ці методи не придатні для довгострокового передбачення, оскільки мають невелику глибину прогнозування, хоча використовують передові математичні підходи і парадигми оброблення даних.

На сьогодні завдання передбачення розвитку безпекового середовища вирішується переважно експертними методами, за якими експерти на основі аналізу сучасних воєнних конфліктів виявляють нові практики у конфліктах i міжнародних відносинах та роблять припущення щодо їх розвитку і застосування у майбутньому. Таку концепцію передбачення можна назвати індуктивною. Наприклад, у статті [2] автори порівнюють гібридні тактики, які Російська Федерація (РФ) застосовувала в конфліктах 3 Грузією і Україною. У статі [3] автори аналізують тактику насильницьких i ненасильницький дій РФ на сході України. Стаття [4] присвячена аналізу соціокультурних причин конфлікту на території України, розвиток яких можна розглядати як важливий елемент прогнозу безпекового середовища. Ці методи мають головну проблему - вони дають змогу проаналізувати лише ті нові властивості, які вже виявились на момент здійснення передбачення. У певному розумінні індуктивну концепцію також можна назвати продовженням існуючих трендів.

Іншою концепцією передбачення можна вважати розгляд безпекових процесів на геополітичному рівні, де доступними для виявлення стають сталі закономірності. Наприклад, у статті [5] автор розглядає дії РФ (окупацію Криму, втручання у східній Україні 
і Сирії) як відповіді на геополітичні дії Заходу, зокрема: розширення НАТО і ЕС. Автор статті [6] дійшов висновку, що конфлікт в Україні став результатом витіснення Російської Федерації 3 Євроатлантичного простору. Важливим висновком дослідження [7] $є$ твердження, що геополітична конкуренція добре пояснює дії РФ в Україні. Концепція геополітичного розгляду $є$ більш придатною для довгострокового передбачення розвитку безпекового середовища. Утім вона також не надає єдиного системного ключа, не визначає тієї системної категорії або першопричини, яка породжує розвиток i обумовлює дії воєнно-політичних сил.
Мета статті полягає у виявленні ключової системної категорії, яка визначатиме розвиток безпекового середовища у довгостроковій перспективі, і предметному розгляді іï з огляду на забезпечення безпеки України.

Застосований nidxid. Безпекове середовище $\epsilon$ складною системою, сукупність елементів якої складають воєнно-політичні сили, а сукупність зав'язків - воєннополітичні відносини між цими силами в усіх сферах життєдіяльності. Системна структура безпекового середовища для випадку двох воєнно-політичних сил схематично показана на рис. 1.

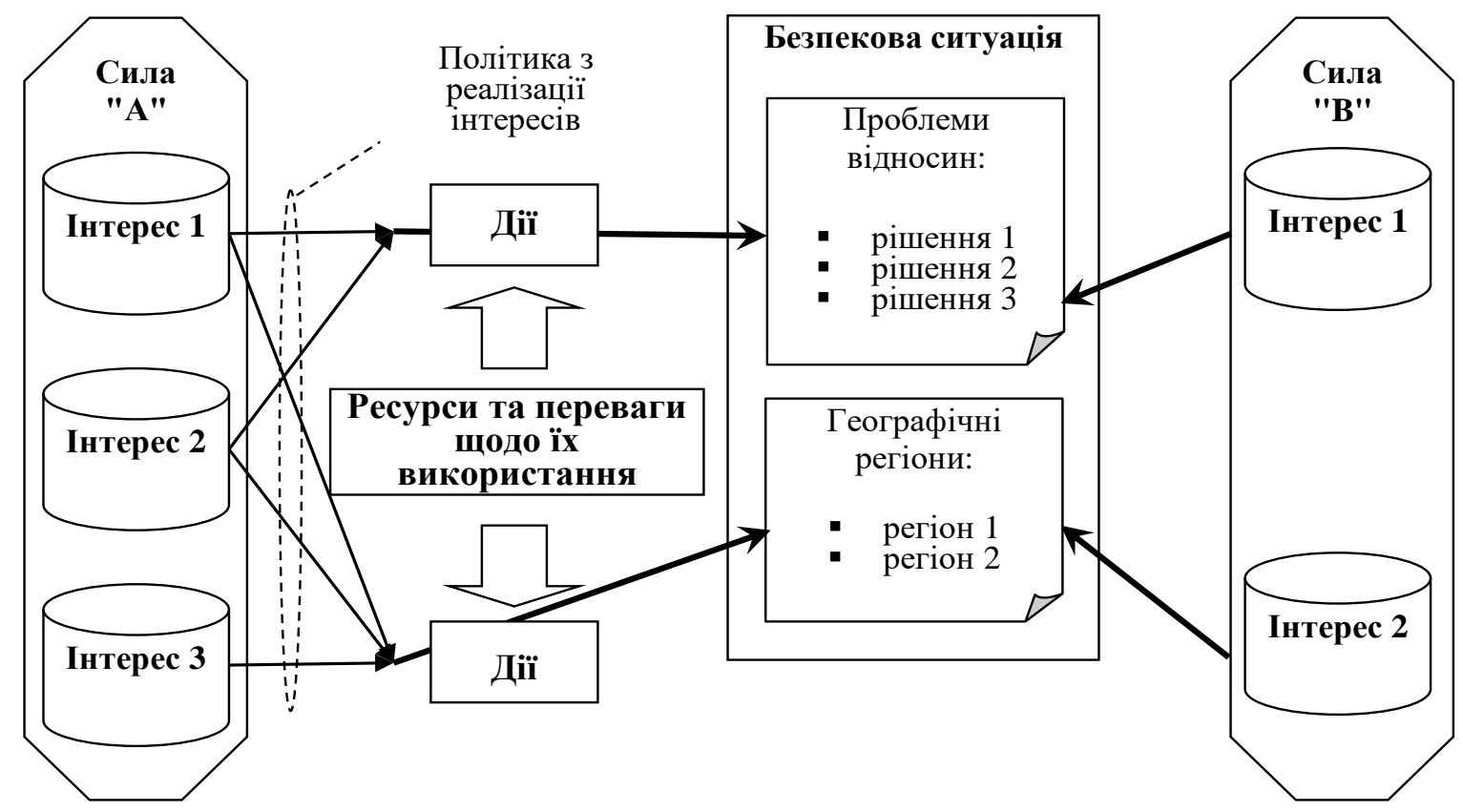

Рис. 1. Системна структура безпекового середовища

Ця структура змістовно не відрізняється від схеми породження воєнно-політичних відносин, розглянутої в [1]. Первинною системною категорією $\epsilon$ інтереси воєннополітичних сил. Інтереси воєнно-політичних сил є тими причинами (стимуляторами), які рухають безпекове середовище. Саме вони i лише вони породжують дії сил, що утворюють безпекову ситуацію 3 певних міжнародних проблем у певних регіонах. Звичайно, під час планування та здійснення дій воєннополітичні сили враховують наявні ресурси i вибудовують певні переваги щодо їх застосування, як правило, залежно від вартості ресурсів i очікуваного ефекту від застосування. У широкому розумінні ресурс $\epsilon$ сукупністю матеріальних i нематеріальних спроможностей сили, які вона має в розпорядженні. На загальному рівні можна виділити три типи ресурсів: людські ресурси, ресурси економіки (такі, що створені людиною: обладнання, інфраструктура, озброєння, технології тощо) i ресурси природного походження (енергоресурси, вода, повітря тощо).

Концепція передбачення, яку запропоновано на основі наведеної структури безпекового середовища, базується на розумінні довгострокового характеру інтересів воєнно-політичних сил. Як показує історичний досвід, зміни інтересів відбуваються лише унаслідок великих подій національного масштабу, які змінюють світорозуміння політичних еліт. Можна бачити докорінні зміни інтересів Німеччини після Другої світової війни, також зміну інтересів колишніх радянських республік, зокрема й України, після розпаду СРСР. Теж саме можна спостерігати в Ірані після ісламської революції.

Отже, якщо інтереси воєнно-політичних сил породжують і визначають головні риси 
безпекового середовища та $є$ сталими впродовж достатньо значущого часового інтервалу, то можна обгрунтовано здійснити передбачення безпекового середовища у довгостроковій перспективі на основі аналізу найбільш узагальнених інтересів воєннополітичних сил, які спостерігаються на сьогодні. Такі найбільш узагальнені інтереси пов'язані із самозбереженням сил i прагненням поступового соціальноекономічного розвитку, тобто насамперед 3 доступом до ресурсів, до ринків збуту і 3 безпекою. Застосовуючи цю концепцію передбачення, розглянемо далі найбільш узагальнені інтереси провідних воєннополітичних сил світу: США, Китаю, ЕС і РФ.

Виклад основного матеріалу. Перед тим як безпосередньо перейти до розгляду інтересів провідних воєнно-політичних сил, оглянемо загальний історичний контекст, у якому проходили зміни цих інтересів до нині. Після цього розглянемо інтереси провідних воєнно-політичних сил, які виявлені на основі багаторічного аналізу воєнно-політичних подій.

Загальний історичний контекст

Майбутнє завжди народжується 3 минулого. Якщо XX століття можна назвати століттям глобальних трансформацій, то початок XXI століття - періодом пошуку нових моделей подальшого розвитку. У ХХ столітті відбулося дві світові війни. Перша світова війна мала результатом кінець існування класичних континентальних імперій: Російської, Австро-Угорської, Османської, Германської. Проте вона ж породила i альтернативу капіталістичному цивілізаційному проєкту - Союз Радянських Соціалістичних Республік. Друга світова війна мала результатом поширення національновизвольного руху у світовому масштабі, розпад найпотужнішої морської імперії Британської i висунення СРСР на перші позиції у світовій політиці. Вона ж дала змогу США накопичити найбільший у світі обсяг золотих запасів і створити глобальну фінансово-економічну систему на основі забезпеченого золотом американського долару, що дало змогу створити стабільні умови для розвитку світової торгівлі. План Маршалла прив'язав економіки Європи i Японії до внутрішнього ринку США, утворивши потужні економічні союзи і на підтримку їх - воєнно-політичні союзи i міжнародні організації як механізми узгодження інтересів і зменшення суперечностей: на інституційному рівні -
Міжнародний валютний фонд, Світову організацію торгівлі, чисельні регіональні організації, а на неформальному рівні "Римський клуб", "Більдербергський клуб" тощо.

У 1976 році світова фінансовоекономічна система була скоригована: замість золота долар США став забезпечуватись нафтою (що автоматично підвищило увагу до Близького Сходу і Китаю), було запроваджено так званий “вашингтонський консенсус", за яким національні валюти мали бути номіновані у доларах США, а курси національних валют - обраховуватись на основі розміру золотовалютних резервів. Одночасно США почали змінювати характер власної економіки, звільняючись від індустріальних виробництв на користь Китаю та інших країн Південно-Східної Азії i роблячи ставку на розвиток власного фінансового сектору. Як наслідок значно активізувався рух капіталів через національні кордони i це потребувало політичного контролю в країнах, що розвиваються, оскільки інвестори хотіли бути впевнені у відсутності політичних ризиків. Так почалася глобалізація, яка базувалась на розвитку інформаційних технологій i транспортної інфраструктури.

У 1991 році внаслідок збігу багатьох причин, які ми зараз не розкриваємо, розпався Радянський Союз, звільнивши місце для замкнення глобальних процесів і залишивши на самоті капіталістичний цивілізаційний проєкт, який, як i будь-який проєкт, мав внутрішні проблеми i через них - час закінчення. Такими проблемами $є$ :

потреба постійної експансії на нові зовнішні ринки, останніми з яких були ринки радянських республік;

подвійність долара США, який $\epsilon$ одночасно i світовою, i національною валютою;

потреба усунення обмежень 3 емісії долара США для забезпечення функціонування зовнішніх ринків.

Як бачимо розвиток цих негативних проблем на сьогодні гіпертрофічний. Першою ластівкою була фінансово-економічна криза 2008 року, яку вдалося загасити, але першопричини залишилися. Невтримно зростає дефіцит торгового балансу США i, як наслідок, державний і корпоративний борг, борги населення. Емісія долара США припинила стимулювати економічне зростання i самих США, i країн, що розвиваються. Непропорційно зросла 
прибутковість

Поширились

фінансового

спекулятивні

сектору.

схеми,

надуваються міхури на фінансових ринках обсяг фінансових деривативів у кілька разів перевищує обсяг усіх світових активів.

Фінансово-економічний потенціал багатьох транснаціональних корпорацій перевищує ВВП окремих регіональних держав. Великі корпорації створили приватні військові компанії, які спроможні здійснювати повнокровні спеціальні операції, перебираючи від держави ii виключне право на застосування засобів збройного насильства. Держави теж почали використовувати приватні військові компанії для вирішення “делікатних" завдань. Розвиток лобізму i фінансових ресурсів корпорацій призвів до інвазії бізнес-інтересів в інтереси держави, підпорядковуючи іiі зовнішню і внутрішню політику збільшенню прибутковості корпоративного сектору і відсунення інтересів суспільства на другій план.

Усе це свідчить про серйозну трансформацію характеру відносин між державою, бізнесом i суспільством та зменшення підстав говорити про стабільність світового розвитку. Нестабільність світових фінансів таким чином породжуе нестабільність світової торгівлі, що відбивається й на соціально-політичних та соціально-економічних процесах. Стає очевидним, що світова фінансово-економічна система вичерпує запас стабільності та потребує змін.

Розуміння проблем капіталістичного проєкту, загроза неконтрольованого розвитку кризових явищ поряд 3 поширенням зброї масового ураження i збільшенням розміру потенційних втрат у разі масштабного конфлікту стимулюють спроби пошуку рішення, яке дало б змогу уникнути негативного розвитку подій і сформувати новий цивілізаційний проєкт. Проте обсяг накопичених фінансово-економічних проблем, небажання йти на поступки заради спільного блага та інші причини не дають змоги цього зробити.

Глобальна фінансово-економічна криза загострила проблеми капіталістичного проєкту i продемонструвала можливість зменшення впливу США i переходу до багатополярної моделі світового порядку, про що одразу зазначили провідні експерти Ф. Фукуяма [8] і Дж. Сорос [9]. Розуміючи це, Китай запропонував масштабний інтеграційний проєкт, спрямований на підвищення свого впливу на європейських ринках i заснований на створенні нових транзитних шляхів “Схід-Захід”. Успіх проєкту надавав змогу Китаю переорієнтувати економіку і політику ЕС і поступово витіснити США з Євразії. Найбільш швидкісні транзитні шляхи до Європи проходять через Росію, яка підтримала китайський проєкт, оскільки він дає змогу розвинути транзитну інфраструктуру і завдяки цьому активізувати розвиток східних територій та посилити вплив Росії на пострадянському просторі через залучення до китайсько-європейської інтеграції. Природно, що США стають зацікавленими у протидії китайському інтеграційному проєкту. У силу цивілізаційної наближеності СС підтримав США, хоча не розірвав остаточно відносини з Китаєм і дав змогу країнам-членам самим вирішувати питання участі в проєкті.

Загалом на сьогодні є підстави припустити, що позитивного виходу знайдено не буде i ситуація рухатиметься у відповідністю 3 логікою взаємодії окремих інтересів окремих сил, без об'єднувальної компоненти і мінімального впорядкування, у напрямі зростання ентропії системи міжнародних відносин i, відповідно, безпекового середовища. Існуючий цивілізаційний проєкт за інерцією продовжує функціонувати, наближуючись до завершення i розпаду, збільшуючи нестабільність безпекового середовища i можливість його вступу на шлях неконтрольованого розвитку. Розрив міжнародних зв'язків обмежує доступ держав до ресурсів, що робіть інтереси світових еліт антагоністичними. Яскравим прикладом $€$ неспроможність $€ \mathrm{C}$ i Великобританії домовитись про вихід останньої із союзу.

Інтереси провідних воєнно-політичних сил

Iнтереси США. Головним довгостроковим інтересом США залишиться збереження однополюсного світового порядку 3 власним домінуванням. США розглядатимуть себе як державу, що має виключну світову місію. Підтримка воєнного потенціалу США на рівні, достатньому для реагування на кризові ситуації в усіх регіонах світу, буде головним воєнним інструментом домінування. Головним невоєнним інструментом домінування буде збереження долара США як валюти, що використовується для розрахунків у світовій торгівлі, контроль над якою гарантуватиме отримання ренти 3 торгових операцій і стабільність власної фінансово-економічної системи. Контроль 
світової торгівлі США забезпечуватимуть через контроль транзиту “критичних" товарів, зокрема енергоносіїв, а також контролю національних еліт у державах, які потенційно можуть впливати на торгівлю такими товарами. Відмова держав від номінованих у доларах США торгових контрактів розглядатиметься США як зазіхання на власне домінування. США також будуть зацікавлені у нарощуванні долі індустріального сектору економіки і збільшенні збуту його продукції, насамперед на величезні споживчі ринки Європи, що поряд з вирівнюванням торгового балансу США одночасно підвищить доларизацію європейської економіки і виключення Європи зі списку потенційних могутніх конкурентів.

3 огляду на реалізацію своїх головних інтересів, США розглядатимуть зближення між Китаєм, ЄС і РФ як найбільшу загрозу домінуванню, оскільки таке зближення означатиме виштовхування США 3 Євразії. Китай зі значними людськими ресурсами і РФ 3 великими природними ресурсами можуть скласти реальну конкуренцію США на глобальному рівні. Аналогічно цьому, утворення технологічно-сировинного кластеру ЄC 3 високими німецькими технологіями та РФ також відштовхуватиме США на узбіччя світових економічних процесів і позбавлятиме США можливості впливу на них. Посилення економічних відносин $\epsilon$ i Китаю зміцнюватиме ланцюжки виробництва і збуту європейських високотехнологічних товарів та заважатиме створенню сприятливих умов для збуту американських товарів у Європі.

$$
\text { Китай залишиться найбільш }
$$

пріоритетною проблемою для США i на сьогодні за деякими показниками економіки перевищує США, а його воєнний потенціал збільшується швидкими темпами. Китай почав формування системи військових баз і у найближчому майбутньому можна очікувати висунення ним претензій на світове панування. $Є \mathrm{C}$, хоча й має потужну економіку, але у воєнній сфері має мінімальний суверенітет. США майже повністю контролює Європу через взаємопроникнення фінансових та економічних зав'язків, за допомогою контролю над ії елітами, розгалуженої мережі військових баз, на деяких 3 них розташована ядерна зброя. РФ навпаки, має добре розвинений ядерний арсенал, але нині i y майбутньому РФ найбільшу увагу приділятиме облаштуванню зони безпеки довкола себе. Недостатній економічний розвиток і політика санкцій 3 боку США, зокрема проти російських капіталів, що зберігаються у західних банках, сприятимуть тривалості цього процесу.

Не єдина, але одна 3 головних ролей у запобіганні зближення між Китаєм, СС і РФ надаватиметься країнам Східної Європи, через які проходять сухопутні шляхи транзиту товарів між ЄС, РФ і Китаєм. Аналогічну роль матиме Чорноморський регіон, контроль над яким дає змогу контролювати поставки російських і середньоазійських енергоносіїв до Європи. Контроль над регіоном Середньої Азії додатково дає змогу США одночасного впливу на:

РФ 3 півдня - проблеми міграції і наркотрафіку;

Китай із заходу - поставки середньоазійських енергоносіїв і вплив на уйгурських сепаратистів;

Середній Схід 3 півночі - поставки середньоазійських енергоносіїв до Пакистану та Індії.

Важливі регіональні інтереси США залишатимуться також на Близькому Сході, де головними регіональними силами $є$ Ізраїль, Саудівська Аравія, Туреччина, Іран і певним чином Єгипет, а ключовою геополітичною точкою - Сирія. Контроль цього регіону дає змогу контролювати країни-споживачі близькосхідних енергоносіїв, зокрема $€ \mathrm{C}$ i Китай, а також стримувати РФ за допомогою цінової конкуренції по енергоносіях. Головними інструментами контролю ситуації, як i раніше, будуть політичні, економічні, міжетнічні і міжконфесійні суперечності між державами регіону. Їx різноманіття $\mathrm{i}$ непримиренний характер не дають змоги говорити про надію на хоча б частковий розв'язок, але для США завжди було домінантою забезпечення безпеки Ізраїлю.

Підвищуватиметься важливість географічно найбільш наближеного до США регіону Латинської Америки. Тут інтереси США концентруватимуться на забезпеченні насамперед політичного контролю Куби, Нікарагуа, Венесуели та інших країн з огляду на запобігання зростанню російського i китайського впливу. Деякі зарубіжні видання заговорили про відродження доктрини Монро [10].

Глобальні інтереси США проєцируються й в інші регіони, але вони $\epsilon$ менш важливими для безпекового середовища 3 погляду України, дотримання якої прозахідного курсу повністю відповідає довгостроковим інтересам США, зокрема 3 огляду на стримування торгових відносин $\mathrm{CC}$ 
3 РФ і Китаєм, підвищення привабливості США як торгового партнера $\mathrm{CC}$, а також посилення впливу в Чорноморському регіоні.

Агресивні дії РФ проти України додають підстав США модернізувати військові структури НАТО, і навіть поліпшити дислокацію, надати поштовх до модернізації власних озброєнь, збільшення оборонних витрат європейськими країнами-членами альянсу (частина яких витрачається для закупівлі американських систем озброєнь) i сформувати у західній суспільній думці позитивне ставлення до жорстких економічних санкцій проти РФ, які полегшують вплив США на європейському ринку. 3 огляду на стримування, агресія РФ проти України і підтримка іiі з боку США призвела до появи на півдні РФ несприятливо налаштованої i досить потужної сусідньої держави, яка триматиме РФ у напрузі, відволікаючи іiі ресурси і зусилля.

Інтереси Китаю. У довгостроковій перспективі Китай продовжить реалізацію так званої концепції “відродження нації”, що матиме на меті перетворення країни на глобальний міжнародний торговоекономічний центр 3 конкурентними спроможностями на світовому рівні. Ключовим інструментом досягнення КНР своїх цілей залишатиметься глобальний інтеграційний проєкт “Один пояс, один шлях". Отже головні інтереси Китаю розташовуватимуться в економічній площині і будуть пов'язані 3 потребою забезпечення безперешкодного доступу на світові споживчі ринки (насамперед європейські) та розширенням присутності юаню у міжнародних розрахунках.

Китай має значні за обсягом, дешеві i дисципліновані людські ресурси, що залишатиметься одним 3 головних факторів високої конкурентоспроможності його економіки. Головним слабким місцем Китаю буде недостатня забезпеченість економіки власними енергоносіями і продовольством, а також велика залежність від ринків збуту експортних товарів середньої ланки виробничих ланцюжків, складність розроблення $\mathrm{i}$ впровадження проривних технологій воєнного призначення. Отже у майбутньому інтереси Китаю будуть спрямовані на забезпечення надійності дешевих поставок енергоносіїв, продовольства i підвищення долі виробництв 3 високою доданою вартістю.

Політична система Китаю, ментальність населення і культурні традиції утруднюють зовнішній вплив на формування його політики, спрямованої на створення нових транзитних маршрутів i розширення економічної присутності в усіх регіонах світу, навіть у проблемних. Китай просуватиме поширення використання національної валюти в міждержавних розрахунках. Можна очікувати, що Китай також розширюватиме військову присутність у ключових для його економіки географічних точках, але утримуватиметься від безпосередньої участі у конфліктних ситуаціях, крім тих, які виникатимуть в безпосередній близькості.

Китай відмовився від участі України у транзитному проєкті “Новий шовковий шлях" через воєнний конфлікт на іï сході і надав перевагу проходженню маршруту через РФ. Утім збережеться певна зацікавленість Китаю в українському споживчому ринку, а також у виробництві сільськогосподарської продукції. У контексті регіональних контактів Китай надаватиме перевагу країнам 3 мінімальним впливом США на формування ї політики. Ураховуючи другорядність України для Китаю і стратегічне партнерство з РФ, можна очікувати, що у відносинах з Україною він підтримуватиме РФ, але не відмовлятиметься повністю від контактів.

Інтереси Свропейського Союзу. Після Другої світової війни європейські країни отримали величезну фінансово-економічну підтримку 3 боку США, які намагалися гарантувати у майбутньому відсутність суперечностей завдяки побудові єдиного економічно благополучного $\mathrm{i}$ розвинутого європейського суспільства. Створення $\mathrm{CC}$ стало логічним наслідком цієї допомоги. До того ж безпеку об'єднання забезпечували США. Утім різноманітність націй 3 різною ментальністю, традиціями, історією відбилася на якості Союзу, особливо після розширення $€ С$ на Східно-Свропейські країни.

ЄC не $€$ повноцінним державним утворенням. Насамперед, він не має єдиного центру управління елементами воєнного потенціалу країн-членів. Забезпечення власної воєнної безпеки практично повністю покладається на НАТО. Крім того, маючи єдину валюту і єдиний емісійний центр, ЄС не має єдиної податкової системи, казначейства і системи бюджетного планування. $\mathrm{He}$ усі члени $Є \mathrm{C} є$ членами фінансового союзу (зони євро). ЄС інституціонально розбалансований і це його головна проблема, усунення якої буде ключовим інтересом у довгостроковій перспективі. 
Інші інтереси матимуть соціальноекономічний вимір. Запаси корисних копалин у Європі переважно виснажені, ресурсні та споживчі ринки часто віддалені, людські ресурси старіють, стратегічні помилки у міграційній політиці породжують релігійноетнічні конфлікти. Економічний розвиток регіонів $\epsilon \mathrm{C} \in$ досить нерівномірним. 3 провідних країн $Є С$ позитивний експортноімпортний баланс вдається мати лише Німеччині та Італії. 3 огляду на це, ключові інтереси ЄС полягатимуть у забезпеченні вигідних умов торгівлі, зокрема, конкурентоспроможності товарів та послуг, контролю ресурсних, споживчих ринків i транзитних регіонів, низьких цін на ресурси, усуненні конкурентних виробництв.

Перевагу у формулюванні інтересів СС матимуть країни 3 великим економічним потенціалом: Німеччина, Франція, Італія. Проте й вони не завжди однаково розумітимуть потрібну спільну політику союзу. Німеччина і Франція намагатимуться посилити вплив на формування внутрішньої політики $\mathrm{CC}$, що викликатиме незадоволення країн з меншим економічним потенціалом.

У регіональному контексті, інтереси Франції та Італії спрямовані на південь, інтереси Німеччини - на центр і схід Європи. Загалом для $\mathrm{EC}$ першочерговий інтерес матимуть такі регіони:

Атлантика - забезпечує торгівлю 3 країнами Західної Африки, а також Північної та Південної Америки;

Північна Африка - забезпечує поставки енергоносіїв до Південної Свропи;

Середземне море, Суец і Червоне море забезпечує транзит енергоносіїв та інші товарні потоки за найкоротшим маршрутом 3 країн Близького та Середнього Сходу, а також Південно-Східної Азії;

Чорне море - забезпечує транзит енергоносіїв 3 РФ і Казахстану, а також $\epsilon$ потенційним маршрутом транзиту енергоносіїв із Закавказзя, Середньої Азії та Ірану;

Білорусь - забезпечує транзит російських енергоносіїв, інші товарні потоки до РФ, а також є потенційним сухопутним шляхом транзиту товарів з Китаю і до Китаю.

Північна Африка зберігатиметься зоною впливу Франції i, частково, Італії, а Білорусь і Україна - зоною інтересів Німеччини. Раніше значення України для Німеччини визначалось ii транзитним положенням. Однак після переорієнтації транзиту російського газу на Балтійське море і рішення про проходження основного транзитного напряму з Китаю через Білорусь Україна й для Німеччини і для ЄС загалом зменшуватиме значення, переводячи його у геополітичну площину відносин з РФ. Дотримання Україною проєвропейського курсу в політиці і економіці та максимальна імплементація Угоди про асоціацію відповідатиме довгостроковим інтересам СС загалом і Німеччини зокрема.

У найближчому майбутньому для Європи зростатиме роль Арктичного регіону і північного морського шляху, який забезпечує у півтори рази більш короткий транзит 3 Північної Свропи до Китаю, ніж шлях через Суецький канал. 3 розвитком потепління в Арктиці також підвищуватиметься доступність неосвоєних північних ресурсів.

Інтереси Російської Федерації. Після розпаду СРСР російська еліта, поступившись багатьма національними інтересами і відчинивши у 90-ті роки економіку для західного капіталу, розраховувала на входження до впливових світових кіл на правах рівноправного партнера. Однак цього не відбулося - західні еліти вважали себе переможцями у холодній війні і не погодились на поступки у впливі, тому на початку 2000 -х років керівництвом РФ спільно 3 національними бізнес-елітами було прийняте рішення на суверенізацію російської політики, яке було втілено в концепцію "ліберальна імперія": сильна держава 3 ринковою економікою. Саме тому серед усіх інтересів РФ на першому плані будуть знаходитись інтереси забезпечення безпеки і можливості суверенно формувати зовнішню і внутрішню політику, рішуче застосовувати силу для досягнення власних інтересів. Росія й надалі буде дотримуватись свого “особливого" шляху розвитку, який характеризуватиметься специфічним державним устроєм, який одночасно поєднуватиме елементи східного авторитаризму та західних демократій.

Останніми роками РФ багато у чому позбавилась деструктивних явищ і тенденцій, була зміцнена вертикаль президентської влади, розмежовані відповідальності центру і регіонів, перебудовано економічні відносини (насамперед в енергетиці), посилено контроль соціально-політичних процесів, відчутно зріс ВВП, який перевищив рівень 1990 року, розгорнуто масштабні програми перебудови економіки і збройних сил. Не зважаючи на це, російська економіка залежить від продажу енергоносіїв і потребує, насамперед, модернізації і забезпечення контрою транзитної інфраструктури. Диверсифікація 
поставок енергоносіїв назовні, будівництво енергетичних потужностей в інших державах, продаж зброї, продовольства також входять до числа першочергових інтересів РФ.

Зростання економічного i воєнного потенціалів РФ дало змогу їй проводити більш агресивну політику на міжнародній арені, що вона наочно продемонструвала в Грузіі, Україні і Сирії. Радикальне оновлення озброєння та військової техніки збройних сил РФ дає змогу стверджувати, що РФ підвищуватиме рішучість до застосування силових інструментів у власній політиці. Географічно інтереси РФ будуть спрямовані на:

Європу як головного споживача російських енергоносіїв;

Східну Європу, Чорне море і Туреччину як транзитні регіони;

Близький Схід i Північну Африку як регіони, конкурентні за видобутком енергоносіїв;

Азійсько-Тихоокеанський регіон як майбутнє джерело зростання світової економіки;

Арктику як транзитний шлях з Свропи i РФ до Китаю i країн АзійськоТихоокеанського регіону.

Для РФ першочерговим інтересом буде забезпечення сприятливих безпекових умов у територіальному просторі довкола власної території, зокрема в:

Білорусі, яка забезпечує безпеку РФ із західного напрямку i безпеку транзитних шляхів до Європи;

Україні, яка важлива 3 огляду на забезпечення РФ безпеки з південно-західного напрямку, а також невідворотності окупації АР Крим і відновлення контролю на сході України;

Чорному морі, через яке здійснюється міжнародна торгівля 3 країнами Південної Європи, Близького Сходу, Північної Африки, Південної Азії;

Кавказі, який $є$ ключовим у розповсюдженні тероризму в РФ;

Каспіï, який важливий для РФ 3 огляду на контроль виходу середньоазійських енергоносіїв через Каспійське море до Європи;

країнах Середньої Азії (Казахстані, Киргизіi, Узбекистані, Туркменії, Таджикистані), які $є$ важливими для РФ зважаючи на забезпечення транзитного сполучення 3 Китаєм, а також розв'язання проблем міграції i транзиту наркотиків, а останнім часом - боротьби розповсюдженням радикального ісламізму i тероризму.

3 розширенням географії бізнесу i торгівлі географія інтересів РФ відповідно розширюватиметься, збільшуючи кількість антагоністичних суперечностей 3 інтересами інших провідних країн. РФ активно виступатиме за перехід до багатополюсного світоустрою, розділеного на регіони, на контроль одного з яких претендуватиме сама.

Не зважаючи на усі недоліки i прорахунки, російська еліта демонструє високий рівень аналітичної підтримки в реалізації власних інтересів. Вона розуміє проблемні питання існуючої соціальноекономічної системи, яка потроху підходить до межі розвитку. Зокрема, гостро постає питання транзиту влади, забезпечення соціальних ліфтів у суспільстві, вирівнювання доходів різних соціальних прошарків i розвитку регіонів. У вирішенні цих питань пріоритети віддаватимуться модернізації системи влади, але не завдяки безпековим інтересам.

Щодо регіону довкола України і самої України інтереси РФ є похідними від інтересів забезпечення безпеки в Чорноморському регіоні і можливості суверенно формувати зовнішню та внутрішню політику держави. Через уповільнення темпів зростання економіки у 2012 році РФ оголосила про намір здійснити модернізаційний ривок для створення автаркії (самодостатньої економіки), але їй не вистачало потрібної ємності ринку (200-250 млн чоловік). Тому РФ ініціювала низку інтеграційних проєктів, зокрема воєнно-політичного характеру. Серед таких проєктів був й вступ України до Митного союзу, який утворив би критичну масу, потрібну для модернізації. Крім того, Україна завжди розглядалася РФ як найкоротший i безперешкодний шлях iз Заходу до Руської рівнини, а АР Крим ключовою геополітичною точкою, контроль над якою забезпечує контроль над Азовським i Чорним морями. Тому позбавлення РФ присутності в Криму розглядалась РФ як безпосередня загроза власній безпеці. 3 огляду на це, довгостроковим інтересом РФ буде забезпечення сприятливості політичного i економічного курсу України завдяки більш тісній економічної, а потім й воєннополітичної інтеграції. РФ також влаштує позаблоковий воєнно-політичний курс України, який гарантував би відсутність на іï території військових баз недружніх держав. 
Висновки. Розглянуті інтереси провідних воєнно-політичних сил окреслюють ïx бачення майбутнього або бажану на їх погляд картину. Сукупність таких картин $е$ внутрішньо суперечливою, а часто антагоністичною. Також ясно, що жодна 3 цих картин не співпадатиме 3 майбутньою реальністю. Яка 3 картин буде найбільш наближена до реальної, залежить від наявності у воєнно-політичної сили ресурсів та ефективності їх застосування.

На сьогодні можна погодитись 3 припущенням про зменшення впливу США. Нажаль для США збіглися в часі три негативні тенденції надвеликої сили. Перша тендениія фінансово-економічні проблеми. Віртуалізована економіка, заснована переважно на фінансовому секторі, майже не працює. Намагання Президента Д. Трампа повернути індустріальні підприємства до податкової території США (тобто збільшити долю реального сектору) виявилися майже марними. Епідемія коронавірусу змусила США підняти державний борг до надзвичайних висот у $\$ 20,5$ млрд у другому кварталі 2020 року. У цьому ж кварталі економіка США обрушилася на $32,9 \%$ абсолютний історичний рекорд. Друга тенденція - розгортання безпрецедентних соціальних протестів, які силові структури не в змозі приборкати і які виникли на фоні розділення політичної еліти на два великих непримиримих табори. Третя тенденція ланка воєнно-політичних прорахунків на міжнародній арені. $€$ цілком очевидними невдачі США у врегулюванні конфліктів і конфліктних ситуацій в Афганістані, Іраку, Сирії, Північній Кореї, Ірані, Венесуелі. За іранською ядерною програмою найближчий союзник - СС відмовився підтримати США. У Німеччині лунають призови виведення американської ядерної зброї. Ці тенденції демонструють проблематичність підтримання США свого статусу абсолютного світового гегемона i підштовхують інші держави шукати інших союзників i iнші шляхи забезпечення своїх інтересів.

Нині зрозуміло, що Китай неспроможній проєктувати силу навіть на Євразійський континент. Тісний союз із Росією міг би дозволити це, але між Китаєм і Росією можна бачити хоча i дружні, але обережні відносини, що більш схиляються до прагматичних. Можливо, це пояснюється не лише територіальними спорами (які мають усе ж меншого значення), а насамперед різними ідеологічними і економічними платформами.
Якби Росія не відмовилась від соціалістичного проєкту у 1990-х роках, стримати зближення 3 Китаєм було б набагато важче. Росія також відчуває проблеми 3 проєктуванням свого впливу на пострадянському просторі, що наочно демонструє ситуація в Україні, Білорусі, Карабаху, Киргизії. Майбутне безпекове середовище також багато у чому буде залежати від того, чи зможе ЄС сконцентрувати свою державність і подолати національні розрізнення, а також від того, чи зможе РФ ламінарно, без біфуркацій забезпечити транзит верховної влади. Якщо відповісти на ці питання позитивно, можна припустити утворення багатополярного світу, де значущими для безпеки України геополітичними кластерами приблизно рівної сили будуть США з Канадою і Британією, СС та Китай з Росією. Кожний кластер не буде спроможним підпорядкувати інші кластери. Тому можна очікувати розгортання серед них конкурентної боротьби, змістом якої буде захоплення буферних зон, забезпечення доступу на сировинні та споживчі ринки, контроль транзитних маршрутів і стримування конкурентів.

Однією з таких зон є Східна Європа, яка розділяє ЄС і Росію, та, відповідно, розриває транзитні шляхи з Китаю до Західної Свропи, утримуючи геополітичні кластери від злиття. Одночасно Східна Європа, до якої належить й Україна, $€$ калейдоскопом націй 3 різним історичним досвідом, цивілізаційними цінностями, політичними тяжіннями. Соціально-політичне різноманіття Східної Європи полегшує намагання грати на цивілізаційних, політичних розрізненнях, історичних образах. Це, поряд з відсутністю зовнішнього впорядкувального впливу, дає підстави дійти висновку про збільшення регіонального потенціалу для виникнення воєнних конфліктів у майбутньому. Зі свого боку, у майбутньому Україна отримує шанс, використовуючи глобальні та регіональні розрізнення і суперечності, вибудувати власну міжнародну політику, спрямовану на реалізацію власних національних інтересів.

\section{ПЕРЕЛІК ВИКОРИСТАНОЇ ЛІТЕРАТУРИ}

1. Бочарніков В. П., Свєшніков С. В., Тимошенко Р. I., Павленко В. I. Технологія аналізу воєнно-політичної обстановки. Київ : НУОУ ім. Івана Черняховського, 2019. 384 с.

2. Lesia Dorosh, Olha Ivasechko, Jaryna Turchyn. Comparative Analysis of the Hybrid Tactics Application by the Russian Federation in Conflicts with Georgia and Ukraine. Central European 
Journal of International and Security Studies. Vol. 13, Issue 2. pp. 48-73.

3. Tatyana Malyarenko \& Stefan Wolff. The logic of competitive influence-seeking: Russia, Ukraine, and the conflict in Donbas. Post-Soviet Affairs. 2018. Vol. 34. Issue 4. pp. 191-212. DOI: https://doi.org/10.1080/ 1060586X.2018.1425083

4. Denys Kiryukhin. Russia and Ukraine: the clash of conservative projects. European Politics and Society. Vol. 17. Issue 4. 2016. pp. 438-452. DOI: https://doi.org/10.1080/23745118.2016.1154130.

5. Hall Gardner. The Russian annexation of Crimea: regional and global ramifications. European Politics and Society. Vol. 17. Issue 4. 2016. pp. 490-505. DOI:

https://doi.org/10.1080/ 23745118.2016.1154190.

6. David Svarin. The construction of 'geopolitical spaces' in Russian foreign policy discourse before and after the Ukraine crisis. Journal of Eurasian
Studies. Vol. 7. Issue 2. 2016. pp. 129-140. DOI: https://doi.org/10.1016/ j.euras.2015.11.002.

7. Roy Allison. Russian 'deniable' intervention in Ukraine: how and why Russia broke the rules. International Affairs. Vol. 90. Issue 6. 2014. pp. 1255-1297. DOI: https://doi.org/10.1111/14682346.12170.

8. Fukuyama: The End of America Inc. URL: https://www.newsweek.com/fukuyama-end-americainc-91715 (дата звернення: 18.08.2020).

9. Von Nathan Gardels. Soros erklärt China zum Gewinner der Finanzkrise. URL: https://www.welt.de/wirtschaft/article2576066/Soros -erklaert-China-zum-Gewinner-der-Finanzkrise.html (дата звернення: 20.08.2020).

10. Francisco Arias Fernández. Trump takes hostility toward Cuba to new heights. URL: https://www.caribbeannewsglobal.com/trump-takeshostility-toward-cuba-to-new-heights/ (дата звернення: 18.08.2020).

Стаття надійшла до редакційної колегії 01.11.2020

\section{Interests of the leading military-political forces as the main determinant of the development of the security environment in the context of Ukraine's security}

\section{Annotation}

Long-term foresight of the evolution of the security environment is the basis for further solving the problems of defense planning in the Ministry of Defense of Ukraine and the Armed Forces of Ukraine. From a scientific view-point, this is a rather difficult problem that can be solved by a systemic representation of the security environment, proceeding from the assumption of the primacy of the interests of military-political forces. If these interests form and determine the security environment and are stable over a sufficiently long-time interval, then we can predict the security environment in the long term based on an analysis of the most generalized interests of military-political forces that we observe today. Applying this concept of foresight, the authors consider the interests of the leading militarypolitical forces: the United States, China, the EU and Russia. The main long-term interest of the United States will remain the preservation of a unipolar world order with its own domination. In accordance with this, the United States is interested in resisting any attempts to increase the influence of other military-political forces. China will be the biggest problem for the United States. China launched a large-scale integration project "One Belt, One Road" aimed at getting closer to the EU and increasing own influence in Europe. If successful, this project will lead to the expulsion of the United States from the Eurasian continent. The interests of the EU have a predominantly economic dimension: access to commodity and consumer markets. At the same time, the interests of the EU are also determined by civilizational proximity to the United States. Russia supported the Chinese integration project. She is interested in strengthening the economy and restoring influence in the post-Soviet space. The interference of the interests of the leading forces paints a contradictory antagonistic picture of the future, which will be determined by the availability of the resources necessary to advance the interests. Today we see a tendency for the US to weaken. But neither China nor Russia will be able to project their strength over the entire Eurasian continent, which determines an increase in the potential for conflict in the future.

Keywords: military and political forces; security environment; defense planning; national interests; foresight. 